\title{
ANALISIS TINGKAT PARTISIPASI WANITA DALAM ANGKATAN KERJA DI JAWA TENGAH PERIODE TAHUN 1982-2000
}

\author{
Eni Setyowati \\ Fakultas Ekonomi Universitas Muhammadiyah Surakarta \\ E-mail: nayla.azka@yahoo.com
}

\begin{abstract}
At industrialization phase, women will be shifted by men because the increasing of unemployment. When economic development reaches a certain stage, the trend of development turned with increasing women employment. Purpose of the research that will be reached is to estimate influence of women unemployment, women resident that managing household, and women residents that still school on the level of women participation in the labor force in Central Java (1982-2000). This study clarifies the factors that influence the level of participation of women in the labor force and improve the existence theory of the labor force participation rate. One way to analyze the effect of short-run and long run is to use a dynamic model. In this research model used is the Engle Granger Error Correction Models (EG-ECM) which based on "granger representation theorem". The result knows the variable having influence which significance in short-run are women resident that managing household and women resident that still school.
\end{abstract}

Key word: women labor force, Engle-Granger, Error Correction Model, employment

\section{PENDAHULUAN}

Sumber daya manusia merupakan salah satu cabang ilmu ekonomi yang khusus membahas dan menguraikan prinsip-prinsip pendayagunaan tenaga kerja dan kemampuan manusia mengolah sumber-sumber produksi dan ketenagakerjaan untuk memenuhi kebutuhan manusia itu sendiri. Ini sejalan dengan arah pembangunan Indonesia, yaitu pembangunan manusia seutuhnya. Pembangunan manusia seutuhnya mencakup berbagai aspek termasuk pendidikan dan latihan serta perlindungan hak-hak dan jaminan hidupnya yang layak (Simanjuntak, 1985)

Masalah ketenagakerjaan merupakan salah satu masalah utama yang kita hadapi.
Jumlah angkatan kerja wanita meningkat dengan pesat. Pada tahun 1995 meningkat menjadi 35,48 persen dari seluruh jumlah angkatan kerja nasional. Tingkat partisipasi angkatan kerja wanita 42,35 persen di perkotaan dan 50,24 persen di pedesaan. Walaupun angkatan kerja wanita terus meningkat, pada umumnya tenaga kerja wanita yang bekerja di sektor formal berada pada jenjang pekerjaan yang paling bawah karena berpendidikan rendah dan tidak memiliki keterampilan yang cukup. Banyak terjadi diskriminasi dalam hal upah, pengembangan karir, dan pemanfaatan fasilitas yang tersedia bagi tenaga kerja. Data tahun 1994 mengungkap bahwa upah pekerja wanita berkisar 50-85 persen dari pekerja pria, meskipun keduanya 
Tabel 1. Jumlah Penduduk Jawa Tengah Menurut Jenis Kelamin dan Sex Ratio Tahun 1996 - 2000

\begin{tabular}{ccccc}
\hline Tahun & Laki-Laki & Perempuan & Jumlah Total & Rasio Jenis Kelamin \\
\hline 1996 & 14.546 .511 & 15.152 .334 & 29.698 .845 & 96.00 \\
1997 & 14.770 .846 & 15.136 .630 & 29.907 .476 & 97.56 \\
1998 & 15.036 .344 & 15.349 .101 & 30.385 .445 & 97.96 \\
1999 & 15.245 .718 & 15.515 .503 & 30.761 .221 & 98.26 \\
2000 & 15.253 .438 & 15.522 .408 & 30.775 .846 & 98.27 \\
\hline
\end{tabular}

Sumber: Biro Pusat Statistik

berpendidikan yang sama. (Bainar, 1999)

Berdasarkan Survei Sosial Ekonomi Nasional (SUSENAS) pada tahun 1999, jumlah penduduk Jawa Tengah tercatat sebesar 30,76 juta jiwa atau sekitar 15 persen dari jumlah penduduk Indonesia. Jumlah penduduk perempuan lebih besar di bandingkan dengan jumlah penduduk laki-laki, ditunjukkan oleh rasio jenis kelamin (rasio penduduk laki-laki terhadap penduduk perempuan) sebesar 98 .

Kondisi ketenagakerjaan di Provinsi Jawa Tengah dapat di lihat dalam Lampiran 1. Untuk mengetahui seberapa jauh sumbangan wanita dalam pembangunan ekonomi, dapat dilihat dari besarnya peranan mereka sebagai angkatan kerja atau istilah ilmiahnya adalah tingkat partisipasi angkatan kerja. Menurut Simanjutak (1985) yang dinamakan angkatan kerja adalah jumlah yang bekerja dan pencari kerja. Sedangkan pengertian tingkat partisipasi angkatan Kerja (TPAK) adalah perbandingan antara jumlah angkatan kerja dengan penduduk usia kerja dalam kelompok yang sama.

Tingkat partisipasi angkatan kerja di pengaruhi oleh faktor-faktor demografi, sosial dan ekonomi. Faktor-faktor ini antara lain: jumlah penduduk yang masih sekolah, jumlah penduduk yang mengurus rumah tangga, tingkat penghasilan dan jumlah tanggungan keluarga yang bersangkutan, umur, tingkat upah dan pendidikan.

Sedangkan Ananta (1990:160) mengemukakan bahwa tingginya tingkat partisipasi angkatan kerja wanita dalam kegiatan ekonomi disebabkan oleh beberapa hal: (1) Adanya perubahan pandangan dan sikap dalam masyarakat tentang sama pentingnya pendidikan bagi kaum pria dan wanita serta semakin disadari perlunya kaum wanita ikut berpartisipasi dalam pembangunan, (2) Adasnya kemauan wanita untuk mandiri dalam bidang ekonomi yaitu berusaha membiayai kebutuhan hidupnya (dan juga kebutuhan hidup orang-orang yang menjadi tanggungannya) dengan penghasilannya sendiri, (3) Adanya kebutuhan untuk menambah penghasilan keluarga, (4) Makin luasnya kesempatan kerja yang bisa menyerap tenaga kerja wanita, misalnya tumbuhnya industri kerajinan tangan dan industri ringan lainnya.

Meningkatnya keterlibatan wanita dalam kegiatan ekonomi dipengaruhi oleh faktorfaktor sosial, ekonomi maupun faktor demografi. Beberapa faktor demografi yang dianggap penting pengaruhnya adalah tingkat pendidikan, jenis kelamin, umur, dan status perkawinan.

Tingkat partisipasi angkatan kerja wanita 
pada umumnya banyak dipengaruhi oleh perubahan dalam struktur ekonomi yang terjadi dalam proses pembangunan. Dalam hal ini terdapat perbedaan pendapat di antara beberapa ahli. Partisipasi angkatan kerja wanita biasanya menunjukkan pola yang berbentuk "U”. Pada tahap awal pembangunan, partisipasi angkatan kerja akan menurun dengan adanya efek industrialisasi, yang kemudian akan naik kembali dengan meningkatnya jumlah yang relatif dari sektor jasa dan munculnya jenis-jenis pekerjaan administrasi atau pekerjaan-pekerjaan kantor lainnya. Pada tahap awal industrialisasi, wanita akan digeser oleh pria karena meningkatnya pengangguran. Setelah pembangunan mencapai tahap tertentu, trend membalik bersamaan dengan meningkatnya kesempatan kerja wanita.

Pola perkembangan tingkat partisipasi angkatan kerja wanita yang berbentuk "U" tersebut agak diragukan kebenarannya, karena antara lain disebabkan oleh peranan wanita dalam sektor pertanian dan sektor non pertanian pada saat awal pembangunan, juga pada distribusi employment secara sektoral, sampai di mana lapangan usaha dan jabatanjabatan pria digantikan oleh wanita.

Berikut ini gambaran perkembangan variabel yang diamati:

(1) Tingkat partisipasi wanita dalam angkatan kerja. Yaitu perbandingan antara jumlah angkatan kerja wanita dengan jumlah penduduk wanita dalam usia kerja. Untuk mengetahui besarnya tingkat partisipasi wanita dalam angkatan kerja di Provinsi Jawa Tengah tahun 1986-2000 dapat dilihat pada Lampiran 2. Data yang digunakan yaitu data berkala (time series).

(2) Jumlah Pengangguran Wanita. Yaitu jumlah penduduk wanita yang berusia 10 tahun ke atas yang sama sekali tidak bekerja dan berusaha mencari pekerjaan. Untuk mengetahui besarnya jumlah pengangguran wanita di provinsi Jawa Tengah tahun 1986-2000 dapat dilihat pada Lampiran 3. Data yang digunakan yaitu data berkala (time series).

(3) Jumlah Penduduk Wanita yang Mengurus Rumah Tangga. Yaitu jumlah penduduk wanita yang berusia 10 tahun ke atas dan hanya berprofesi sebagai ibu rumah tangga atau mengurus keluarganya, tanpa bekerja atau mencari pekerjaan untuk memperoleh penghasilan atau keuntungan. Untuk mengetahui pertumbuhan jumlah penduduk wanita yang mengurus rumah tangga di provinsi Jawa Tengah tahun 1986-2000 dapat dilihat pada Lampiran 4. Data yang digunakan yaitu data berkala (time series).

(4) Jumlah penduduk wanita yang masih sekolah. Yaitu jumlah penduduk wanita yang berusia 10 tahun ke atas yang masih duduk di bangku pendidikan mulai dari tingkat Sekolah Dasar sampai dengan Perguruan Tinggi. Untuk mengetahui pertumbuhan jumlah penduduk wanita yang masih sekolah di provinsi Jawa Tengah tahun 1986-2000 dapat dilihat pada Lampiran 5. Data yang digunakan yaitu data berkala (time series).

Berdasarkan latar belakang tersebut, maka penelitian ini akan melihat analisis pengaruh pengangguran wanita, penduduk wanita yang mengurus rumah tangga, dan penduduk wanita yang masih sekolah terhadap tingkat partisipai wanita dalam angkatan kerja di Jawa Tengah.

Tinjauan Pustaka. Pertumbuhan penduduk berpengaruh terhadap penduduk usia kerja dan pada gilirannya nanti juga berpengaruh terhadap pertumbuhan angkatan kerja. Perbandingan antara jumlah angkatan ker- 
ja dengan jumlah penduduk dalam usia kerja di sebut dengan tingkat partisipasi angkatan kerja.

Secara singkat partisipasi angkatan kerja dapat dirumuskan sebagai berikut (Mantra, 2000, 321):

TPAK $=\frac{\text { Jumlah Angkatan Kerja }}{\text { Jumlah Tenaga Kerja }} \times 100$

dimana: TPAK adalah Tingkat Partisipasi Angkatan Kerja, AK adalah Angkatan Kerja, TK adalah Tenaga Kerja

Semakin besar tingkat partisipasi angkatan kerja akan menyebabkan semakin besar jumlah angkatan kerja. Begitu pula sebaliknya, semakin besar jumlah penduduk yang masih sekolah dan yang mengurus rumah tangga akan menyebabkan semakin besar jumlah yang tergolong bukan angkatan kerja dan akibatnya semakin kecil tingkat partisipasi angkatan kerja.

Angka TPAK dapat digunakan sebagai dasar untuk mengetahui penduduk yang aktif bekerja ataupun mencari pekerjaan. Bila angka TPAK kecil maka dapat diduga bila penduduk usia kerja banyak yang tergolong bukan angkatan kerja baik yang sedang sekolah maupun mengurus rumah tangga dan sebagainya. Dengan demikian angka TPAK banyak dipengaruhi oleh faktor jumlah penduduk yang masih sekolah maupun penduduk yang mengurus rumah tangga. Kedua faktor tersebut dapat pula dipengaruhi oleh keadaan ekonomi dan sosial budaya. Oleh karena itu di negara-negara yang sudah maju TPAK cenderung tinggi pada golongan umur dan tingkat pendidikan tertentu. Biasanya perkembangan suatu negara atau daerah tingkat partisipasi angkatan kerja perempuan menurut golongan umur dan pendidikan yang sering diperhatikan. Pola TPAK perempuan dapat memberikan petunjuk yang berguna dalam mengamati arah dan perkembangan aktifitas ekonomi di suatu negara atau daerah. Berlainan dengan laki-laki, umumnya perempuan mempunyai peran ganda sebagai ibu yang melaksanakan tugas rumah tangga, mengasuh dan membesarkan anak dan bekerja untuk menambah penghasilan keluarga. (Mantra,2000: 322)

Banyak faktor yang mempengaruhi tingkat partisipasi wanita dalam angkatan kerja, faktor-faktor tersebut di antaranya adalah:

(1) Jumlah pengangguran wanita. Jumlah pengangguran wanita yang meningkat akan menyebabkan timbulnya kekecewaan yang dirasakan oleh penganggur karena kebutuhan keuangan dan biaya fisik untuk mencari upah yang lebih rendah apabila dibandingkan dengan sulitnya mencari pekerjaan (Zainab Bakir, 1984) menurut Aske Theo Komalig (1985: 27), hubungan tingkat partisipasi angkatan kerja wanita dengan tingkat penganggur yang semakin kuat apabila diperhitungkan tenaga kerja putus asa sangat di pengaruhi oleh keadaan pasar tenaga kerja semakin besar permintaan akan tenaga kerja wanita maka semakin banyak tenaga kerja beralih masuk dalam angkatan kerja dan akan menyebabkan menurunnya jumlah tenaga kerja putus asa.

Secara keseluruhan, jumlah pertambahan penduduk wanita yang menganggur lebih banyak dibandingkan dengan penduduk lakilaki. Demikian juga dengan pertumbuhan pengangguran terbuka penduduk wanita yang meningkat cukup pesat. Keadaan ini diduga karena telah meningkatnya tingkat pendidikan mereka. Pendidikan akan menambah pengetahuan dan penalaran mereka serta meningkatkan opportunity cost karena tidak ak- 
tifnya dalam bekerja dan dapat mengatasi rintangan-rintangan sosial budaya yang membatasi penduduk wanita bekerja di luar rumah tangga.

Meningkatnya jumlah penyediaan tenaga kerja terdidik dari penduduk wanita muda akan mendorong permintaan akan tenaga kerja yang berpendidikan lebih tinggi. Dengan bertambahnya jumlah tenaga kerja yang berpendidikan tertentu di pasar tenaga kerja, pengusaha akan cenderung meningkatkan syarat tingkat pendidikan tenaga kerja yang diberi pekerjaan, terutama pada jabatan-jabatan tertentu yang sebelumnya dilaksanakan oleh tenaga kerja yang berpendidikan relatif rendah, tanpa meningkatkan upah dari jabatan tersebut. Di lain pihak banyak penduduk wanita muda yang berpendidikan memasuki angkatan kerja dengan harapan memperoleh pekerjaan yang serupa dengan yang ditangani pekerja-pekerja yang berpendidikan sama dengan mereka. Dengan demikian, meskipun permintaan akan tenaga kerja yang berpendidikan naik tetapi penawaran selalu melampaui jumlah yang dibutuhkan.

Perbedaan tingkat pengangguran penduduk wanita menurut tingkat pendidikan kemungkinan besar karena peranan perbedaan pada kelompok umur muda (10-24 tahun). Hal ini kemungkinan karena: (a) Dengan meingkatnya tingkat pendidikan, terutama pada kelompok umur muda, cenderung mempengaruhi mereka untuk bekerja di luar rumah tangga dan memilih pekerjaan yang dianggap sesuai; (b) tingkat pengangguran yang tinggi dari penduduk wanita muda yang berpendidikan relatif tinggi kemungkianan karena yang terdidik lebih tercatat sebagai pencari kerja daripada tercatat bukan sebagai anngkatan kerja, karena pada umumnya mereka tercatat bukan sebagai angkatan kerja, karena pada umumnya mereka berusaha mendapatkan pekerjaan-pekerjaan yang bersifat formal yang mengharuskan mereka untuk secara aktif melaksanakan kegiatan tersebut; (c) Tingkat pengangguran penduduk wanita yang hampir sama pada kelompok umur di atas 25 tahun pada berbagai tingkat pendidikan, diperkirakan karena beberapa hal, anatara lain mereka yang telah tamat sekolah dan lama mencari pekerjaan menjadi putus asa sehingga keluar dari angkatan kerja, baik untuk sementara ataupun secara permanen.

(2) Jumlah penduduk wanita yang mengurus rumah tangga. Simanjuntak (1985), berpendapat bahwa salah satu faktor yang mempengaruhi tingkat partisipasi angkatan kerja wanita adalah jumlah penduduk yang mengurus rumah tangga. Kenyataan bahwa jauh lebih banyak jumlah penduduk wanita yang mempunyai kegiatan utama di dalam rumah tangga dibanding dengan jumlah penduduk wanita yang bekerja dan bahwa jauh lebih banyak jumlah penduduk wanita yang mengurus rumah tangga dibandingkan dengan jumlah penduduk laki-laki, akan menyebabkan semakin kecil tingkat partisipasi kerja.

Beberapa penelitian yang dilakukan di berbagai daerah menunjukkan, walaupun wanita telah menyumbangkan jumlah waktu yang sedikit lebih rendah daripada laki-laki dalam mencari nafkah, namun wanita jauh lebih banyak menghabiskan waktunya untuk mengurus rumah tangga Bahkan fakta lain telah mengungkapkan bahwa wanita hanya mempunyai waktu untuk istirahat yang jauh lebih sedikit daripada laki-laki. Hal ini menunjukkan peranan wanita dalam kehidupan rumah tangga (keluarga) tidak dapat diabaikan.

(3) Jumlah penduduk wanita yang masih sekolah. Peningkatan partisipasi angkatan 
kerja merupakan sumbangan yang penting dalam pembangunan nasional. Oleh karena itu, tinggi rendahnya penduduk wanita yang masih sekolah bisa dipakai sebagai ukuran sejauh mana suatu daerah mampu mengikuti perkembangan pembangunan yang ada. Banyak sedikitnya penduduk wanita yang masih sekolah wanita yang bersangkutan untuk meningkatkan pengetahuan, keterampilan dan keahlian. Semakin tingginya tuntutan terhadap pendidikan maka cenderung mengurangi tingkat partisipasi wanita dalam angkatan kerja. Tuntutan pendidikan ke arah yang lebih tinggi seiring dengan kemajuan zaman. Persepsi masyarakat tentang pentingnya memperoleh pendidikan setinggi-tinginya akan cenderung menurunkan tingkat partisipasi wanita dalam angkatan kerja.

Menurut Harris (1995), orang-orang yang mempunyai tingkat pendidikan yang lebih tinggi mungkin akan lebih lama menganggur sambil mencari pekerjaan dibandingkan dengan orang-orang yang tingkat pendidikannya lebih rendah. Ada dua alasan yang membenarkan hal tersebut. Pertama, orang yang lebih terpelajar dapat menghadapi kemungkinan tawaran upah yang lebih luas, sehingga keuntungan yang mungkin diperoleh dengan masa pencarian yang lebih lama akan lebih besar. Kedua, pendapatan keluarga dan status ekonomi serta tingkat pendidikan memungkinkan orang berpendidikan dapat membiayai kebutuhan pokok selama masa pencarian kerja.

\section{METODE PENELITIAN}

\section{Alat analisis}

Alat analisis yang digunakan dalam penelitian ini adalah Engle-Granger Error Correction Model (EG-ECM). Model koreksi ke- salahan mampu meliputi banyak variabel dalam menganalisis fenomena ekonomi jangka panjang serta mengkaji konsistensi model empiris dengan teori ekonomi.

Penurunan model dinamis Engle-Granger Error Correction Model (EG-ECM) dilakukan dengan metode Autoregressive Distributed Lags (ADL) dengan cara memasukkan variabel kelambaman dalam model. Secara umum dapat dituliskan sebagai berikut (Maddala, 2001, 565).

$\Delta_{\mathrm{yt}}=\operatorname{lagged}(\Delta \mathrm{y}, \Delta \mathrm{x})-\lambda \mathrm{u}_{\mathrm{t}-1}+\varepsilon_{\mathrm{t}} \quad 0<\lambda<1$

dimana $\mathrm{U}_{\mathrm{t}}$ adalah residual regresi kointegrasi dan $\lambda$ merupakan parameter penyesuaian jangka pendek. Pendekatan ini konsisten dengan Granger Representation Theorem yaitu jika $x_{t}$ dan $y_{t}$ berkointegrasi, maka residual regresi kointegrasi $u_{t}$ juga akan stasioner.

Menurut Engle dan Granger (1987), estimasi model dinamis dengan pendekatan ini memerlukan dua tahapan (Two-stage Procedure Engle-Granger Error Correction Model). Jika dimisalkan persamaan regresi kointegrasi yang diestimasi adalah $\mathrm{y}_{\mathrm{t}}=\beta_{0}+\beta_{1} \mathrm{x}_{\mathrm{t}}$ dengan residual kointegrasinya $u_{t}=y_{t}-\beta_{0}+$ $\beta_{1} x_{t}$, maka pengujian yang akan dilakukan adalah sebagai berikut (Harris, 1995).

Tahap pertama, mengestimasi parameter jangka panjang. Hal ini dilakukan dengan melakukan regresi persamaan kointegrasi $y_{t}=$ $\beta_{0}+\beta_{1} x_{t}$, jika $y_{t}$ dan $x_{t}$ berkointegrasi, maka koefisien parameter jangka panjang $\beta_{0}$ dan $\beta_{1}$ akan konsisten.

Tahap kedua adalah melakukan estimasi terhadap persamaan $\Delta \mathrm{y}_{\mathrm{t}}=\operatorname{lagged}(\Delta \mathrm{y}, \Delta \mathrm{x})$ $\lambda \mathrm{u}_{\mathrm{t}-1}+\varepsilon_{\mathrm{t}}$. Banyaknya lag yang digunakan dalam estimasi jangka pendek ini dapat diketahui dengan metode general to specific yang 
jang, (2) Hasil estimasi OLS dengan model koreksi kesalahan E-G menunjukkan bahwa variabel yang berpengaruh dan signifikan secara statistik dalam jangka pendek adalah jumlah penduduk wanita yang mengurus rumah tangga dan jumlah penduduk wanita yang masih sekolah mempunyai pengaruh yang negatif terhadap tingkat partisipasi wanita dalam angkatan kerja, (3) Hasil estimasi jangka panjang menunjukkan bahwa variabel yang berpengaruh dan signifikan secara statistik adalah variabel jumlah penduduk wanita yang masih sekolah mempunyai pengaruh yang negatif terhadap tingkat partisipasi wanita dalam angkatan kerja.

Penelitian ini hanya terbatas pada (1) data sekunder sehingga belum didapatkan informasi yang lengkap mengenai realitas di lapangan, (2) Variabel yang digunakan hanya tiga yaitu jumlah penduduk wanita yang mengurus rumah tangga, jumlah penduduk wanita yang masih sekolah dan jumlah pengangguran wanita, (3) Analisis data yang digunakan analisis statistik dan ekonometrik, sehingga kurang memberikan informasi yang lengkap scara kualitatif.

Penelitian selanjutnya hendaknya (1) memperhatikan data primer sehingga bisa memperoleh informasi yang lengkap, (2) Hendaknya memasukkan variabel lain, misalnya; pengangguran pria, pendidikan pria, dan lain-lainnya, (3) Hendaknya bisa mengembangkan kebaruan ilmu dengan penelitian yang sifatnya kualitatif.

\section{DAFTAR PUSTAKA}

Badan Pusat Statistik. (2000). Jawa Tengah dalam angka tahun 2000, Jawa Tengah: BPS.

Ananta, Aris, (1990), Ekonomi Sumberdaya
Manusia, Lembaga Demografi FE UI, Jakarta.

Bainar (1999), Jagat Wanita dalam Pandangan Tokoh Dunia, Jakarta: Pustaka Cidesindo.

Danny S, Tritjahjo,(2000), Perkembangan Tenaga Kerja Wanita di Sektor Informal: Hasil Analisis dan Proxy Data Sensus Penduduk, Dian Ekonomi Vol VI.No.2 UKSW. Salatiga

Dickey, David and Wayne A Fuller (1979). Distribution of the Estimator for Autoregressive Time Series with a Unit Root. Journal of the American Statical Association.

Dickey, David and Wayne A Fuller. (1981) Like Lihood Ratio Statistics for Auto Regressive Time Series with a Unit Roof Econometrica, Vol 49.

Engel, R.F. and C.W.J Granger (1987) Cointegration and Error Coerrection Representation, Estimation and Testing Econometrica.

Gurajati, Damodar N (1995) Basic Econometrics Third Edition. Singapore: Mc.Graw Hill Book. Co

Harris, Richard (1995) Using Cointegration Analysis in Econometric Modelling. New Jersey: Prentice Hall/Harvester Wheatsheaf.

Ihromi, Omas Tapi, (1990), Para Ibu yang Berperan Tunggal dan yang Berperan Ganda, Jakarta: FE UI.

Insukindro (1991) Regresi Linear Lancung dalam Analisis Ekonomi, Suatu Tinjauan dengan Satu Studi Kasus di Indonesia JEBI Vol 6 No.1

Ihromi, Omas Tapi (1990) Para Ibu yang Berperan Tunggal dan yang Berperan Ganda. Jakarta: FE UI. 
Komaliq, Aske Theo (1985) Pengangguran di Indonesia Suatu Analisis Data Sensus 1971 dan 1980, Yogyakarta: Pusat Penelitian Kependudukan UGM.

Mantra, Ida B., (1995). Pengantar Studi Demografi, Jakarta: Nur Cahaya.

Mantra, Ida B., (2000). Demografi Umum, Yogyakarta: Pustaka Pelajar.

Mukharomah,Wafiatun.(2000). Pemanfaatan Tenaga Kerja Wanita di Perkotaan. Studi Kasus di Kodya Surakarta, EMPIRIKA. No. 26. BPPE FE UMS. Desember.
Simanjutak, Payaman J (1985) Pengantar Ekonomi Sumber Daya Manusia. Jakarta: LPFE UI.

Suroto (1992) Strategi Pembangunan dan Perencanaan Kesempatan Kerja, Yogyakarta: Gajahmada University Press.

Wisadirana, Darsono.(2004). Peran Ekonomi Wanita dalam Rumah Tangga Studi Pada Masyarakat Peternak Sapi Perah, Media Ekonomi, Vol.14 No.21, FE UMM. Agustus.

\section{LAMPIRAN}

Lampiran 1. Jumlah Penduduk dan Tenaga Kerja di Jawa Tengah tahun 1995-1999

\begin{tabular}{lccccc}
\hline Tahun & 1995 & 1996 & 1997 & 1998 & 1999 \\
\hline Penduduk & & & & & \\
Jumlah (juta jiwa) & 29,52 & 29,7 & 29,91 & 30,39 & 30,76 \\
Pertumbuhan (\%) & 0,7 & 0,6 & 0,7 & 1,6 & 1,2 \\
Tenaga Kerja & & & & & \\
Jumlah (juta jiwa) & 23,65 & 23,77 & 24,26 & 24,57 & 25,12 \\
Pertumbuhan (\%) & 0,3 & 0,5 & 2,1 & 1,3 & 2,2 \\
\hline
\end{tabular}

Sumber: Biro Pusat Statistik

Lampiran 2. Tingkat Partisipasi Wanita dalam Angkatan Kerja di Provinsi Jawa Tengah Tahun 1986-2000 (dalam persen)

\begin{tabular}{ccc}
\hline No. & Tahun & TPAK (wanita) \\
\hline 1. & 1986 & 52,82 \\
2. & 1987 & 51,46 \\
3. & 1988 & 53,08 \\
4. & 1989 & 52,78 \\
5. & 1990 & 51,78 \\
6. & 1991 & 51,96 \\
7. & 1992 & 51,23 \\
8. & 1993 & 51,89 \\
9. & 1994 & 50,71 \\
10. & 1995 & 47,23 \\
11. & 1996 & 51,30 \\
12. & 1997 & 50,65 \\
13. & 1998 & 58,75 \\
14. & 1999 & 59,31 \\
15. & 2000 & 54,26 \\
\hline
\end{tabular}

Sumber : Biro Pusat Statistik 
Lampiran 3. Jumlah Pengangguran Wanita di Provinsi Jawa Tengah Tahun 1986-2000 (dalam ribuan jiwa)

\begin{tabular}{ccc}
\hline No. & Tahun & Jumlah Pengangguran Wanita \\
\hline 1. & 1986 & 120.195 \\
2. & 1987 & 130.849 \\
3. & 1988 & 65.290 \\
4. & 1989 & 135.764 \\
5. & 1990 & 134.111 \\
6. & 1991 & 132.399 \\
7. & 1992 & 141.434 \\
8. & 1993 & 227.253 \\
9. & 1994 & 242.430 \\
10. & 1995 & 413.377 \\
11. & 1996 & 250.358 \\
12. & 1997 & 261.741 \\
13. & 1998 & 325.330 \\
14. & 1999 & 240.852 \\
15. & 2000 & 334.883 \\
\hline
\end{tabular}

Sumber : Biro Pusat Statistik

Lampiran 4. Jumlah Penduduk Wanita yang Mengurus Rumah Tangga di Provinsi Jawa Tengah Tahun 1986-2000 (dalam ribuan jiwa)

\begin{tabular}{ccc}
\hline No. & Tahun & $\begin{array}{c}\text { Jumlah Penduduk Wanita yang } \\
\text { Mengurus Rumah Tangga }\end{array}$ \\
\hline 1. & 1986 & 2.430 .787 \\
2. & 1987 & 2.480 .025 \\
3. & 1988 & 2.487 .055 \\
4. & 1989 & 2.418 .188 \\
5. & 1990 & 2.618 .897 \\
6. & 1991 & 2.678 .068 \\
7. & 1992 & 2.801 .828 \\
8. & 1993 & 2.939 .979 \\
9. & 1994 & 2.893 .773 \\
10. & 1995 & 3.665 .307 \\
11. & 1996 & 3.033 .473 \\
12. & 1997 & 3.266 .399 \\
13. & 1998 & 2.974 .398 \\
14. & 1999 & 3.002 .717 \\
15. & 2000 & 3.333 .057 \\
\hline
\end{tabular}

Sumber: Biro Pusat Statistik 
Lampiran 5. Jumlah Penduduk Wanita yang Masih Sekolah di Provinsi Jawa Tengah Tahun 1986-2000 (dalam ribuan jiwa)

\begin{tabular}{ccc}
\hline No. & Tahun & Jumlah Penduduk Wanita yang Masih Sekolah \\
\hline 1. & 1986 & 1.862 .611 \\
2. & 1987 & 1.987 .052 \\
3. & 1988 & 1.976 .938 \\
4. & 1989 & 2.098 .934 \\
5. & 1990 & 2.050 .096 \\
6. & 1991 & 1.980 .040 \\
7. & 1992 & 1.998 .612 \\
8. & 1993 & 1.948 .641 \\
9. & 1994 & 2.203 .439 \\
10. & 1995 & 2.168 .726 \\
11. & 1996 & 2.164 .742 \\
12. & 1997 & 2.026 .118 \\
13. & 1998 & 750.297 \\
14. & 1999 & 743.134 \\
15. & 2000 & 1.424 .996 \\
\hline
\end{tabular}

Sumber : Biro Pusat Statistik 
Lampiran 6. Uji Akar Unit dengan DF Test

\begin{tabular}{|c|c|c|c|c|}
\hline Variabel & $\begin{array}{l}\text { Lag } \\
\text { Imodel }\end{array}$ & AIC & $\begin{array}{l}\text { Dicky Fuller } \\
\text { t-statistik }(\gamma)\end{array}$ & $\begin{array}{l}\text { Mackinnon } \\
\text { critical value }\end{array}$ \\
\hline \multirow[t]{3}{*}{ LnY } & $\begin{array}{r}1 \\
\operatorname{Mod} 1\end{array}$ & -2.341076 & -2.304508 & $\begin{array}{r}1 \%-4.1366 \\
5 \%-3.1483 \\
10 \%-2.7180\end{array}$ \\
\hline & $\begin{array}{r}1 \\
\operatorname{Mod} 2\end{array}$ & -2.497950 & -2.532731 & $\begin{array}{r}1 \%-2.7989 \\
5 \%-1.9725 \\
10 \%-1.6307\end{array}$ \\
\hline & $\begin{array}{r}1 \\
\operatorname{Mod} 3\end{array}$ & -2.260724 & -2.413013 & $\begin{array}{r}1 \%-4.9893 \\
5 \%-3.8730 \\
10 \%-3.3820\end{array}$ \\
\hline \multirow[t]{3}{*}{ LnX1 } & $\begin{array}{r}1 \\
\operatorname{Mod} 1\end{array}$ & 0.603640 & -4.331513 & $\begin{array}{r}1 \%-4.1366 \\
5 \%-3.1483 \\
10 \%-2.7180\end{array}$ \\
\hline & $\begin{array}{r}1 \\
\operatorname{Mod} 2\end{array}$ & 0.830521 & -3.349214 & $\begin{array}{r}1 \%-2.7989 \\
5 \%-1.9725 \\
10 \%-1.6307\end{array}$ \\
\hline & $\begin{array}{r}1 \\
\operatorname{Mod} 3\end{array}$ & 0.608850 & -4.363858 & $\begin{array}{r}1 \%-4.9893 \\
5 \%-3.8730 \\
10 \%-3.3820\end{array}$ \\
\hline \multirow[t]{3}{*}{ LnX2 } & $\begin{array}{r}1 \\
\operatorname{Mod} 1\end{array}$ & -1.719166 & -2.833838 & $\begin{array}{r}1 \%-4.1366 \\
5 \%-3.1483 \\
10 \%-2.7180\end{array}$ \\
\hline & $\begin{array}{r}1 \\
\operatorname{Mod} 2\end{array}$ & -1.716542 & -2.460855 & $\begin{array}{r}1 \%-2.7989 \\
5 \%-1.9725 \\
10 \%-1.6307\end{array}$ \\
\hline & $\begin{array}{r}1 \\
\operatorname{Mod} 3\end{array}$ & -1.586376 & -2.747216 & $\begin{array}{r}1 \%-4.9893 \\
5 \%-3.8730 \\
10 \%-3.3820\end{array}$ \\
\hline \multirow[t]{3}{*}{ LnX3 } & $\begin{array}{r}1 \\
\operatorname{Mod} 1\end{array}$ & 0.813519 & -3.484553 & $\begin{array}{r}1 \%-4.1366 \\
5 \%-3.1483 \\
10 \%-2.7180\end{array}$ \\
\hline & $\begin{array}{r}1 \\
\operatorname{Mod} 2\end{array}$ & 0.709581 & -3.521853 & $\begin{array}{r}1 \%-2.7989 \\
5 \%-1.9725 \\
10 \%-1.6307\end{array}$ \\
\hline & $\begin{array}{r}1 \\
\operatorname{Mod} 3\end{array}$ & 0.693226 & -3.914333 & $\begin{array}{r}1 \%-4.9893 \\
5 \%-3.8730 \\
10 \%-3.3820\end{array}$ \\
\hline
\end{tabular}

Catatan: Data Hasil Olahan. 
Lampiran 7. Uji Akar Unit dengan ADF test

\begin{tabular}{|c|c|c|c|c|}
\hline Variabel & $\begin{array}{l}\text { Lag / } \\
\text { model }\end{array}$ & AIC & $\begin{array}{l}\text { Dicky Fuller } \\
\text { t-statistik }(\gamma)\end{array}$ & $\begin{array}{l}\text { Mackinnon } \\
\text { critical value }\end{array}$ \\
\hline \multirow[t]{3}{*}{ LnY } & $\begin{array}{r}0 \\
\operatorname{Mod} 1\end{array}$ & -2.587515 & -3.799209 & $\begin{array}{r}1 \%-4.0681 \\
5 \%-3.1222 \\
10 \%-2.7042\end{array}$ \\
\hline & $\begin{array}{r}0 \\
\text { Mod } 2\end{array}$ & -2.729911 & -3.939047 & $\begin{array}{r}1 \%-2.7760 \\
5 \%-1.9699 \\
10 \%-1.6295\end{array}$ \\
\hline & $\begin{array}{r}0 \\
\operatorname{Mod} 3\end{array}$ & -2.447721 & -3.539981 & $\begin{array}{r}1 \%-4.8870 \\
5 \%-3.8288 \\
10 \%-3.3588\end{array}$ \\
\hline \multirow[t]{3}{*}{ LnX1 } & $\begin{array}{r}0 \\
\operatorname{Mod} 1\end{array}$ & 0.964414 & -5.711534 & $\begin{array}{r}1 \%-4.0681 \\
5 \%-3.1222 \\
10 \%-2.7042\end{array}$ \\
\hline & $\begin{array}{r}0 \\
\text { Mod } 2\end{array}$ & 0.893501 & -5.642211 & $\begin{array}{r}1 \%-2.7760 \\
5 \%-1.9699 \\
10 \%-1.6295\end{array}$ \\
\hline & $\begin{array}{r}0 \\
\text { Mod } 3\end{array}$ & 1.117125 & -5.437740 & $\begin{array}{r}1 \%-4.8870 \\
5 \%-3.8288 \\
10 \%-3.3588\end{array}$ \\
\hline \multirow[t]{3}{*}{$\operatorname{LnX2}$} & $\begin{array}{r}0 \\
\text { Mod } 1\end{array}$ & -1.980144 & -6.587137 & $\begin{array}{r}1 \%-4.0681 \\
5 \%-3.1222 \\
10 \%-2.7042\end{array}$ \\
\hline & $\begin{array}{r}0 \\
\text { Mod } 2\end{array}$ & -1.970948 & -6.203268 & $\begin{array}{r}1 \%-2.7766 \\
5 \%-1.9699 \\
10 \%-1.6295\end{array}$ \\
\hline & $\begin{array}{r}0 \\
\operatorname{Mod} 3\end{array}$ & -1.836996 & -6.305229 & $\begin{array}{r}1 \%-4.8870 \\
5 \%-3.8288 \\
10 \%-3.3588\end{array}$ \\
\hline \multirow[t]{3}{*}{ LnX3 } & $\begin{array}{r}0 \\
\operatorname{Mod} 1\end{array}$ & 0.935891 & -2.598911 & $\begin{array}{r}1 \%-4.0681 \\
5 \%-3.1222 \\
10 \%-2.7042\end{array}$ \\
\hline & $\begin{array}{r}0 \\
\text { Mod } 2\end{array}$ & 0.786428 & -2.739556 & $\begin{array}{r}1 \%-2.7760 \\
5 \%-1.9699 \\
10 \%-1.6295\end{array}$ \\
\hline & $\begin{array}{r}0 \\
\operatorname{Mod} 3\end{array}$ & 1.089607 & -2.251529 & $\begin{array}{r}1 \%-4.8870 \\
5 \%-3.8288 \\
10 \%-3.3588\end{array}$ \\
\hline
\end{tabular}

Catatan: Data hasil olahan

Keterangan variabel: $Y$ adalah tingkat partisipasi wanita dalam angkatan kerja, $X 1$ adalah jumlah Pengangguran Wanita, X2 adalah Jumlah Penduduk Wanita yang Mengurus Rumah Tangga, X3 adalah Jumlah penduduk wanita yang masih sekolah. 


\title{
PEDOMAN PENULISAN \\ JURNAL EKONOMI PEMBANGUNAN FAKULTAS EKONOMI UNIVERSITAS MUHAMMADIYAH SURAKARTA
}

Terbit: 2 kali dalam setahun pada bulan Juni dan Desember

\author{
Akreditasi Jurnal: \\ KEPUTUSAN DIREKTUR JENDERAL PENDIDIKAN TINGGI \\ KEMENTERIAN PENDIDIKAN NASIONAL NOMOR: 51/DIKTI/Kep./2010 \\ (masa berlaku Juni 2010 s.d Juni 2013)
}

1. Artikel ditulis dengan bahasa Indonesia atau bahasa Inggris dalam bidang kajian masalah ekonomi dan pembangunan.

2. Substansi artikel diharapkan sejalan dengan Panduan Akreditasi Berkala Ilmiah 2006, yang diterbitkan Direktorat Penelitian dan Pengabdian kepada Masyarakat (DP2M) Direktorat Jenderal Pendidikan Tinggi Republik Indonesia).

3. Artikel ditulis dengan kaidah tata bahasa Inggris ataupun bahasa Indonesia yang baik dan benar.

4. Sistematika Penulisan

Sistematika penjenjangan atau peringkat judul artikel dan bagian-bagiannya dilakukan dengan cara berikut:

(1) Judul ditulis dengan huruf besar semua, di bagian tengah atas pada halaman pertama

(2) Sub Bab Peringkat 1 ditulis dengan huruf pertama besar semua di tengah/center

(3) Sub Bab Peringkat 2 ditulis dengan huruf besar-kecil rata tepi kiri

- Sistematika artikel hasil penelitian adalah: judul; nama penulis (tanpa gelar akademik); nama dan alamat institusi, alamat e-mail penulis, abstrak (maksimum 150 kata) yang berisi tujuan, metode, dan hasil penelitian; kata kunci (4-5 kata kunci); pendahuluan (tanpa ada subjudul) yang berisi latar belakang, sedikit tinjauan pustaka, dan tujuan penelitian; metode; hasil penelitian dan pembahasan; kesimpulan; daftar rujukan (hanya memuat sumber-sumber yang dirujuk).

\section{JUDUL UTAMA:}

\section{Sub Judul}

Penulis $1^{1}$ dan Penulis $2^{2}$

${ }^{1}$ Nama instansi/lembaga Penulis 1

Alamat lengkap instansi penulis, nomor telepon instansi penulis

${ }^{2}$ Nama instansi/lembaga Penulis 2

Alamat lengkap instansi penulis, nomor telepon instansi penulis

(jika nama instansi penulis 1 dan 2 sama, cukup ditulis satu saja)

E-mail penulis 1 dan 2:

Abstrak: Abstrak dalam bahasa Indonesia (125 - 150 kata)

Kata kunci: 4 - 5 katal frase

Abstract: Abstract in english (125 - 150 words)

Keywords: $4-5$ words/ phrase

\section{PENDAHULUAN}

(berisi latar belakang, sekilas tinjauan pustaka, dan tujuan penelitian, yang dimasukkan dalam paragraf paragraf bukan dalam bentuk subbab)

METODE PENELITIAN

Subbab

Subbab

...

\section{HASIL ANALISIS DAN PEMBAHASAN}

Pedoman Penulisan Jurnal Ekonomi Pembangunan FE Universitas Muhammadiyah Surakarta 


\title{
Subbab
}

\section{KESIMPULAN \\ DAFTAR PUSTAKA}

- Sistematika artikel hasil pemikiran adalah: judul; nama penulis (tanpa gelar akademik); nama dan alamat institusi, alamat e-mail penulis, abstrak (maksimum 150 kata); kata-kata kunci (4-5 kata kunci); pendahuluan (tanpa ada subjudul) yang berisi latar belakang dan tujuan atau ruang lingkup tulisan; bahasan utama (dapat dibagi ke dalam beberapa sub-judul); penutup atau kesimpulan; daftar rujukan (hanya memuat sumber-sumber yang dirujuk).

\section{JUDUL UTAMA: \\ Sub Judul}

Penulis $1^{1}$ dan Penulis $2^{2}$

${ }^{1}$ Nama instansi/lembaga Penulis 1

Alamat lengkap instansi penulis, nomor telepon instansi penulis

${ }^{2}$ Nama instansi/lembaga Penulis 2

Alamat lengkap instansi penulis, nomor telepon instansi penulis

(jika nama instansi penulis 1 dan 2 sama, cukup ditulis satu saja)

E-mail penulis 1 dan 2 :

\author{
Abstrak: Abstrak dalam bahasa Indonesia (125--150 kata) \\ Kata kunci: 4 - 5 katal frase \\ Abstract: Abstract in english (125 - 150 words) \\ Keywords: $4-5$ words/ phrase

\section{PENDAHULUAN PEMBAHASAN \\ KESIMPULAN} \\ DAFTAR PUSTAKA
}

5. Artikel diketik pada kertas kwarto berkualitas baik. Dibuat sesingkat mungkin sesuai dengan subyek dan metode penelitian (bila naskah tersebut ringkasan penelitian), biasanya 20-25 halaman dengan spasi satu, untuk kutipan paragraf langsung diindent (tidak termasuk daftar pustaka).

6. Marjin atas, bawah, dan samping harus dibuat paling tidak satu inci.

7. Abstrak, ditulis satu paragraf sebelum isi naskah. Abstrak dalam dua bahasa yaitu bahasa Indonesia dan bahasa Inggris. Abstrak tidak memuat uraian matematis, dan mencakup esensi utuh penelitian, metode dan pentingnya temuan dan saran atau kontribusi penelitian.

8. $\quad$ a. Penulisan numbering diintegrasikan dalam paragraf, contohnya:

Tujuan dilakukannya penelitian ini adalah: (1) Untuk mengetahui apakah CSR berpengaruh positif terhadap nilai perusahaan, (2) Untuk mengetahui apakah persentase kepemilikan manajemen berperan sebagai variabel moderating dalam hubungan antara CSR dengan nilai perusahaan, dan (3) Untuk mengetahui apakah tipe industri berperan sebagai variabel moderating dalam hubungan antara CSR dengan nilai perusahaan?

b. Penulisan bullet juga diintegrasikan dalam paragraf dengan menggunakan tanda koma pada antarkata/kalimat tanpa bullet.

9. Tabel dan gambar, untuk tabel dan gambar (grafik) sebagai lampiran dicantumkan pada halaman sesudah teks. Sedangkan tabel atau gambar baik di dalam naskah maupun bukan harus diberi nomor urut.

- Tabel atau gambar harus disertai judul. Judul tabel diletakkan di atas tabel sedangkan judul gambar diletakkan di bawah gambar.

Pedoman Penulisan Jurnal Ekonomi Pembangunan FE Universitas Muhammadiyah Surakarta 
- Sumber acuan tabel atau gambar dicantumkan di bawah tabel atau gambar.

- Garis tabel yang dimunculkan hanya pada bagian header dan garis bagian paling bawah tabel sedangkan untuk garis-garis vertikal pemisah kolom tidak dimunculkan.

Contoh: Tabel

Tabel 1. Bentuk-bentuk Mobilitas Penduduk

\begin{tabular}{llll}
\hline No & Bentuk Mobilitas & Batas Wilayah & Batas Waktu \\
\hline 1. & Ulang-alik (commuting) & Dukuh (dusun) & 6 jam atau lebih dan kembali pada hari yang sama \\
2. & Menginap/mondok di daerah tujuan & Dukuh (dusun) & Lebih dari satu hari tetapi kurang dari 6 bulan \\
3. & Permanen/menetap di daerah tujuan & Dukuh (dusun) & 6 bulan atau lebih menetap di daerah tujuan \\
\hline
\end{tabular}

Sumber: Ida Bagoes, 2000

\section{Contoh: Gambar}

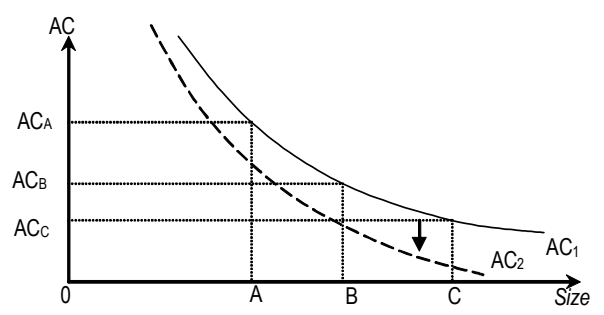

Sumber: Saunders (1997: 291)

Gambar 2. Dampak Peningkatan Teknologi

10. Cara penulisan rumus, Persamaan-persamaan yang digunakan disusun pada baris terpisah dan diberi nomor secara berurutan dalam parentheses (justify) dan diletakkan pada margin kanan sejajar dengan baris tersebut. Contoh:

$\mathrm{wt}=\mathrm{f}\left(\mathrm{y}_{\mathrm{t}}, \mathrm{k}_{\mathrm{t}}, \mathrm{w}_{\mathrm{t}-1}\right)$

11. Keterangan Rumus ditulis dalam satu paragraf tanpa menggunakan simbol sama dengan (=), masingmasing keterangan notasi rumus dipisahkan dengan koma. Contoh:

Dimana $\mathbf{w}$ adalah upah nominal, $\mathbf{y t}$ adalah produktivitas pekerja, kt adalah intensitas modal, $\mathbf{w}_{\mathbf{t}-\mathbf{1}}$ adalah tingkat upah periode sebelumnya.

12. Perujukan sumber acuan di dalam teks dengan menggunakan nama akhir dan tahun. Kemudian bila merujuk pada halaman tertentu, penyebutan halaman setelah penyebutan tahun dengan dipisah titik dua. Untuk karya terjemahan dilakukan dengan cara menyebutkan nama pengarang aslinya.

Contoh:

- Yuni (2008: 23) memandang bahwa .....

- Fatimah dan Daryono (1997) menunjukkan adanya ....

- Didit dkk (2007) berkesimpulan bahwa....

- Untuk meningkatkan perekonomi daerah .... (Yuni, Triyono, dan Agung Riyardi, 2009).

- Maya (2009) berpendapat bahwa ....

13. Setiap kutipan, baik langsung maupun tidak langsung, harus diikuti sumbernya (lihat poin no. 10) dan dicantumkan juga dalam daftar pustaka. Contoh:

Di dalam paragraf isi tercantum kutipan dari: Buiter (2007:15) berpendapat bahwa...

Maka dalam daftar pustaka harus ada sumber referensinya seperti berikut:

Buiter, W. H., (2002). The Fiscal Theory of the Price Level: A Critique, Economic Journal, 112(127): 459-480.

Pedoman Penulisan Jurnal Ekonomi Pembangunan FE Universitas Muhammadiyah Surakarta 
14. Sedapat mungkin pustaka-pustaka yang dijadikan rujukan adalah pustaka yang diterbitkan 10 tahun terakhir dan diutamakan dari jurnal ilmiah.

15. Unsur yang ditulis dalam daftar pustaka secara berturut-turut meliputi: (1) nama akhir pengarang, nama awal, nama tengah, tanpa gelar akademik, (2) tahun penerbitan, (3) judul termasuk subjudul, (4) tempat penerbitan, (5) nama penerbit.

Contoh cara penulisan:

a. Format rujukan dari buku: Nama pengarang, (tahun), Judul Buku, edisi, Kota penerbit, Nama penerbit. Jika penulis sebagai editor tunggal, ditulis (Ed.) di belakang namanya. Ditulis (Eds.) jika editornya lebih dari satu orang. Kemudian bila pengarang lebih dari tiga orang, dituliskan nama pengarang pertama dan yang lain disingkat 'dkk' (pengarang domestik) atau 'et.al.' (pengarang asing).

Enders, W., (2004), Applied Econometric Time Series, Second edition, New York: John Wiley \& Sony Inc. Purnomo, Didit (Ed.). (2005). The Role of Macroeconomic Factors in Growth. Surakarta: Penerbit Muhamadiyah University Press.

b. Format rujukan dari artikel dalam buku ditulis: Nama editor (Ed.), (tahun), Judul tulisan/karangan. Judul buku, hlm atau pp., kota penerbit: nama penerbit

Daryono (Ed.). (2005). Concept of Fiscal Decentralization and Worldwide Overview (hlm. 12-25). Surakarta: Penerbit Muhammadiyah University Press.

c. Format rujukan dari artikel dalam jurnal/majalah/koran: Nama pengarang (tahun). judul tulisan/ karangan. Nama jurnal/majalah/koran, hlm atau pp., volume (nomor), halaman. Jika rujukan koran tanpa penulis, nama koran ditulis diawal.

Rodden, J., (2002). The dilemma of Fiscal Federalism: Grants and Fiscal Performance arround the World. American Journal of Political Science, 46 (3): 670-687.

Triyono (2008). Perimbangan Keuangan Pusat dan Daerah Sebagai Pelaksanaan Desentralisasi Fiskal Efek. Warta Ekonomi, Vol. 4, Agustus: 46-48.

Haryanto, S., (2007, 13 November). Desentralisasi Fiskal dan Pembangunan Ekonomi. Harian Jakarta, hlm.4.

Harian Jogjakarta, (2007, 1 April). Hubungan Keuangan Pusat-Daerah di Indonesia. hlm. 4.

d. Format rujukan dari internet, tanggal akses dicantumkan.

Setyowati, E.,. Keuangan Publik dan Sistem Harga. http://www.ekonomipublik.com/akt/pdf/akt452.pdf.

Diakses tanggal 27 Mei 2009.

\section{Pengiriman Artikel}

1. Artikel dikirimkan sebanyak 2 eksemplar hardcopy, dan softcopy berupa file. File bisa dikirim melalui email jepums@yahoo.co.id atau dalam media cd.

2. Artikel yang dikirim wajib dilampiri biodata ringkas pendidikan termasuk catatan riwayat karya-karya ilmiah sebelumnya yang pernah dipublikasikan, insitusi dan alamatnya, nomor telpon kontak atau e-mail penulis.

3. Penulis yang menyerahkan artikelnya kepada editor atau penerbit, harus menjamin bahwa naskah yang diajukan tidak melanggar hak cipta, belum dipublikasikan atau telah diterima untuk dipublikasi oleh jurnal lainnya.

4. Kepastian pemuatan atau penolakan naskah akan diberitahukan secara tertulis. Penulis yang artikelnya dimuat mendapatkan jurnal tersebut. Artikel yang tidak dimuat tidak akan dikembalikan.

\section{Alamat Redaksi Jurnal Ekonomi Pembangunan Fakultas Ekonomi Universitas Muhammadiyah Surakarta: \\ Redaksi Jurnal Ekonomi Pembangunan Fakultas Ekonomi Universitas Muhammadiyah Surakarta Jalan A. Yani Tromol Pos I Pabelan SURAKARTA 57102 Telp. 0271-717417 psw 229}

Pedoman Penulisan Jurnal Ekonomi Pembangunan FE Universitas Muhammadiyah Surakarta 
TENTANG JURNAL:

\title{
JURNAL EKONOMI PEMBANGUNAN
}

Kajian Masalah Ekonomi dan Pembangunan

ISSN 1411- 6081

\author{
Pimpinan Redaksi \\ Didit Purnomo
}

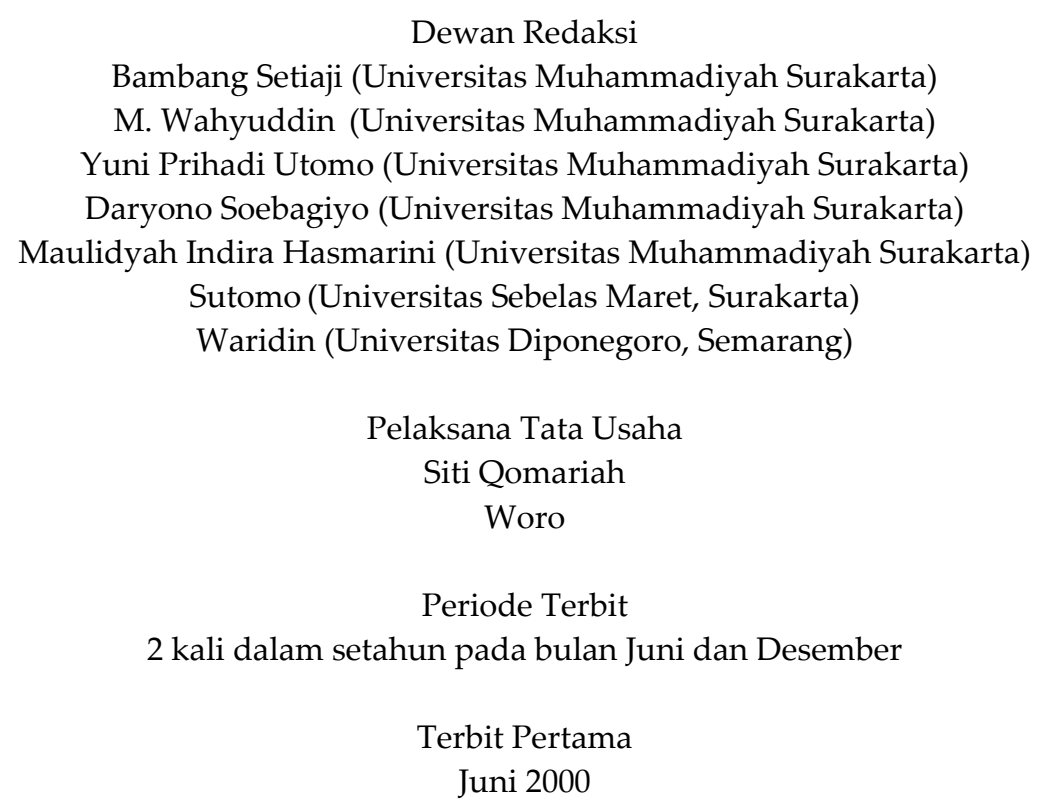

Jurnal EKONOMI PEMBANGUNAN merupakan jurnal ilmiah yang berisikan hasil penelitian dan kajian teoritis mengenai masalah-masalah ekonomi dan pembangunan, khususnya di Indonesia. Diterbitkan oleh Balai Penelitian dan Pengembangan Ekonomi Fakultas Ekonomi Universitas Muhammadiyah Surakarta.

Redaksi menerima sumbangan tulisan yang belum pernah diterbitkan atau dalam proses terbit oleh media lain. Naskah diketik di atas kertas HVS kuarto spasi satu sepanjang lebih kurang 20-25 halaman, dengan format seperti tercantum pada prasyarat naskah jurnal EKONOMI PEMBANGUNAN di halaman belakang. Naskah yang masuk akan dievaluasi dan disunting untuk keseragaman format dan tata cara lainnya.

Alamat Penyunting dan Tata Usaha: Subag Tata Usaha Fakultas Ekonomi Universitas Muhammadiyah Surakarta, Jl. A. Yani, Tromol Pos 1, Pabelan, Surakarta 57102; Telpon (0271) 717417 psw 229,

E-mail: jepums@yahoo.co.id

Website: http://www.ums.ac.id atau http://www.paradejurnal.wordpress.com

Simak informasi jurnal: http://www.paradejurnal.wordpress.com

Admin: Mirat Sidharta. SE

Pedoman Penulisan Jurnal Ekonomi Pembangunan FE Universitas Muhammadiyah Surakarta 